\title{
Enkephalins in large bowel malignancy and in acute appendicitis
}

\author{
W. G. DAVIS, W. P. TORMEY, AND P. V. DELANEY \\ From the Department of Pharmacology, University College, Dublin, and the Departments of Medicine and \\ Surgery, Trinity College, Dublin, at St. James Hospital, Dublin
}

SUMMARY Leucine and methionine enkephalins were measured by biological assay in normal colon, adenocarcinoma of the colon, carcinoma of the caecum, and in normal and inflamed appendix. Methionine enkephalin levels in both the adenocarcinomas and inflamed appendices were significantly higher than in normal controls. No significant change occurred in leucine enkephalin levels. The caecal tumours were anaplastic and contained no demonstrable opioid activity.

The discovery of endogenous substances with morphine-like activity followed the identification and characterisation of specific opiate receptors (Goldstein et al., 1971; Pert and Snyder, 1973; Simon et al., 1973; Terenius, 1973), and the development of good in vitro bioassay methods (Kosterlitz and Waterfield, 1975.)

The pentapeptides, leucine and methionine enkephalin, which exhibit opioid activity, were isolated initially from pig and cow brain (Hughes et al., 1975) and, subsequently, from peripheral tissues including the gastrointestinal tract (Hughes et al., 1977). They were postulated to function as neurotransmitters at morphine sensitive synapses (Kosterlitz and Hughes, 1975), and immuno-histochemical studies suggested the presence of 'enkephalinergic' neurones in the myenteric plexus of the gut (Elde et al., 1975), while an immunocytochemical determination of a methionine enkephalin-like peptide in human gut was reported by Polak et al., (1977).

The object of this study was to confirm the presence of enkephalins in human gut tissues, using a biological assay, and to ascertain possible differences in enkephalin levels between normal and diseased bowel.

\section{Methods}

Normal and neoplastic colon and normal and inflamed appendix were obtained at operation from patients who had received no narcotic analgesic premedication. Each specimen was immediately bisected and one part was sent for histological examination, the other was immediately frozen in solid carbon dioxide.

Received for publication 16 May 1979
All 12 diseased appendices were acutely inflamed and non-perforated. The seven control appendices were free of any inflammatory tissue. The three caecal tumours were very anaplastic and undifferentiated. The other 10 tumours were adenocarcinomas and were from the rectum, sigmoid, or descending colon. They were classified as Dukes stage B or C (Dukes, 1940). Normal colon was taken from the disease-free proximal end of five colectomy specimens, resected because of adenocarcinoma. Separation of tissue layers within the tumour mass proved impossible and the enkephalin extraction was performed on the whole remaining sample. All specimens were treated similarly and any mesenteric fat was removed.

\section{EXTRACTION}

The extraction method of Hughes et al. (1977) was used. The tissues were minced with scissors, and homogenised in ice-cold $0.1 \mathrm{M} \mathrm{HCl}(5 \mathrm{ml} / \mathrm{g}$ tissue). The homogenate was centrifuged at $4^{\circ} \mathrm{C}$ for 30 minutes at $10000 \mathrm{~g}$ and the supernatant was chromatographically separated, by passing through an Amberlite XAD 2 column $(10 \times 1.0 \mathrm{~cm})$ at a flow rate of $1.0 \mathrm{ml} / \mathrm{min}$. The column was then washed with $30 \mathrm{ml} 1.0 \mathrm{M} \mathrm{HCl}$ followed by $80 \mathrm{ml}$ distilled water $(2.0 \mathrm{ml} / \mathrm{min})$ and the enkephalins were eluted with $40 \mathrm{ml}$ of $90 \%(\mathrm{v} / \mathrm{v})$ methanol.

The eluate was dried under reduced pressure at $40^{\circ} \mathrm{C}$ and stored at $-16^{\circ} \mathrm{C}$. The dried extracts were redissolved in $30 \mu \mathrm{l}$ methanol containing $1.0 \mu \mathrm{g}$ ascorbic acid and spotted $(15 \mu \mathrm{l} / \mathrm{spot})$ on silica gel thin layer chromatography plates. The plates were developed with a mixture of ethyl acetate:pyridine: water:acetic acid (50:22:13:6). Control plates, spotted with commercial enkephalins were run in parallel and the peptides were located with ninhydrin 
spray. Corresponding areas on the experimental plates were removed, retained in a cotton wool plug, eluted with $0.5 \mathrm{ml}$ saline, and directly assayed for opioid activity.

\section{BIOASSAY}

Opioid peptide activity was measured by bracket assay on the mouse vas deferens preparation electrically stimulated at $0.1 \mathrm{~Hz}$ with rectangular pulses of $0.3 \mathrm{~ms}$. The tissue was suspended in magnesiumfree Krebs medium within a $5 \mathrm{ml}$ tissue bath. Opioid activity in the thin layer chromatography extracts was assayed against the corresponding commercial enkephalin and opiate receptor specificity was confirmed with naloxone.

Enzyme studies were used to show the peptide nature of the active principles. Commercial enkephalin $(1.0 \mu \mathrm{g})$ or $0.1 \mathrm{ml}$ eluate were mixed with $0.2 \mu \mathrm{g}$ leucine aminopeptidase or carboxypeptidase $\mathrm{A}$, incubated at $37^{\circ} \mathrm{C}$ for 30 minutes immediately assayed for opioid activity.

\section{Results}

Commercial leucine and methionine enkephalins gave thin layer chromatography $R f$ values of 0.43 and 0.32 respectively. Eluates taken from the same areas of the experimental plates produced a dose-related, naloxone reversible inhibition of the electrically stimulated mouse vas deferens. The assayed amounts of enkephalin activity in neoplastic, inflamed, and normal gut tissues taken from different patients are shown in the table expressed in pmol per $\mathrm{g}$ wet tissue. Analysis of the data with Student's $t$ test revealed significantly higher methionine enkephalin levels in adenocarcinoma of the colon $(\mathrm{P}<0.001)$ and in inflamed appendix $(P<0.025)$ than in the control tissues. The changes in leucine enkephalin levels in both conditions were not statistically significant. The undifferentiated caecal carcinomas contained no demonstrable enkephalins. The peptide nature of the eluate was confirmed by the loss of opiate activity after incubation with the peptidases.

\section{Discussion}

The presence of enkephalins in normal human gastrointestinal tissue confirms the immunocytochemical studies of Polak et al. (1977). Hughes et al. (1977) found that over $95 \%$ of the opioid activity in guinea-pig brains and ilea had separation characteristics similar to enkephalins. The relative amounts of leucine and methionine enkephalins in human gut are similar to those reported in the intestines of experimental animals. Enkephalins were demonstrated in the myenteric plexus of the gut (Elde et al., 1976) and shown to inhibit myenteric neurone firing (North and Williams, 1976), thereby slowing gut motility.

The undifferentiated carcinomas of the caecum did not contain any measurable amounts of enkephalins. This finding is consistent with the high degree of dedifferentiation of these three tumour specimens. Mild diarrhoea rather than constipation is the most common bowel symptom in these carcinomas (Goligher, 1967).

All of the left-sided colonic carcinomas had recognisable invasion of the submucosa and muscularis coat resulting in disruption of the myenteric plexus. As a consequence, motility disturbances would be expected and altered bowel habit, often manifested as increasing constipation, is a frequent accompaniment of carcinomas of the descending and sigmoid colon and of the rectum (Goligher, 1967).

The intraluminal pressure in the appendix increases in acute inflammation (Ackerman, 1968) leading to distension of the visceral walls. Prolonged distension of guinea-pig ileum segments in vitro resulted in inhibition of peristalsis and the bath solution surrounding these preparations inhibited peristalsis in non-distended control segments. Both of these effects were reversed by naloxone (Van Nueten et al., 1976). A similar naloxone-reversed inhibition of ileal motility was produced by methionine enkephalin (Van Nueten et al., 1977). A recent history of constipation is common in nonperforated acute appendicitis (Allen, 1965) and may

Table Enkephalin levels in pmol/g wet tissue (mean $\pm S E)$

\begin{tabular}{|c|c|c|c|}
\hline Sample & Number of patients & Methionine enkephalin & Leucine enkephalin \\
\hline $\begin{array}{l}\text { Normal colon } \\
\text { Adenocarcinoma of colon } \\
\text { Carcinoma of caecum } \\
\text { Normal appendix } \\
\text { Inflamed appendix }\end{array}$ & $\begin{array}{l}5 \\
10 \\
3 \\
7 \\
12\end{array}$ & $\begin{array}{l}34 \pm 4 \cdot 3 \\
74 \pm 5 \cdot 3^{*} \\
\text { ND } \\
44 \pm 9 \cdot 3 \\
85 \pm 11 \cdot 2 \dagger\end{array}$ & $\begin{array}{l}17 \pm 2 \cdot 4 \\
19 \pm 5 \cdot 1 \\
N D \\
16 \pm 2 \cdot 4 \\
24 \cdot 5 \pm 3 \cdot 6\end{array}$ \\
\hline
\end{tabular}

ND: Not detectable

Values significantly different from normal by Student's $t$ test: ${ }^{*} P<0.001$ and ${ }_{\mathbf{P}}<0.025$. 
reflect a local opioid effect after tissue distension.

The increased enkephalin levels found in both the malignant and inflamed gut tissues studied suggest a possible local role for enkephalins in the pathophysiology of the associated motility disturbances.

\section{References}

Ackerman, L. V. (1968). Surgical Pathology. 4th edn, p. 388. Mosby: St. Louis.

Allen, J. G. (1965). Surgery: Principles and Practice, p. 963. Pitman Medical: London.

Dukes, C. E. (1940). Cancer of the rectum; analysis of 1000 cases. Journal of Pathology and Becteriology, 50, 527-539.

Elde, R., Hökfelt, T., Johansson, O., and Terenius, L. (1976). Immuno-histochemical studies using antibodies to leucine enkephalin: initial observations on the nervous system of the rat. Neuroscience, 1, 359-351.

Goldstein, A., Lowney, L. I., and Pal, B. K. (1971). Stereospecific and nonspecific interactions of the morphine congener levorphanol in subcellular fractions of mouse brain. Proceedings of the National Academy of Sciences of the United States of America, 68- 17421747.

Goligher, J. C. (1967). Surgery of the Anus, Rectum and Colon, 2nd edn, pp. 500-503. Bailliere, Tindall and Cassell: London.

Hughes, J., Kosterlitz, H. W., and Smith, T. W. (1977). The distribution of methionine enkephalin and leucineenkephalin in the brain and peripheral tissue. British Journal of Pharmacology, 61, 639-647.

Hughes, J., Smith, T. W., Kosterlitz, H. W., Fothergill, L. A., Morgan, B. A., and Morris, H. R. (1975). Identification of two related pentapeptides from the brain with potent opiate agonist activity. Nature, $\mathbf{2 5 8 ,}$ 577-579.

Kosterlitz, H. W., and Hughes, J. (1975). Some thoughts on the significance of enkephalin, the endogenous ligand. Life Sciences, 17, 91-96.

Kosterlitz, H. W., and Waterfield, A. A. (1975). In vitro models in the study of structure activity relationships of narcotic analgesics. Annual Review of Pharmacology, $15,29-47$.

North, R. A., and Williams, J. T. (1976). Enkephalin inhibits firing of myenteric neurones. Nature, 264, 460461.

Pert, C. B., and Snyder, S. H. (1973). Opiate receptor: demonstration in nervous tissue. Science, 179, 10111014.

Polak, J. M., Sullivan, S. N., Bloom, S. R., Facer, P., and Pearse, A. G. E. (1977) Enkephalin - like immunoreactivity in the human gastrointestinal tract. Lancet, 1 , 972-974.

Simon, E. J., Hiller, J. M., and Edelman, I. (1973). Stereospecific binding of the potent narcotic analgesic ${ }^{3} \mathrm{H}$ Etorphine to rat-brain homogenate. Proceedings of the National Academy of Sciences of the United States of America, 70, 1947-1949.

Terenius, L. (1973). Characteristics of the 'receptor' for narcotic analgesics in synaptic plasma membrane fraction from rat brain. Acta Pharmacologica et Toxicologica, 33, 377-384.

Van Nueten, J. M., Janssen, P. A. J., and Fontaine, J. (1976). Unexpected reversal effects of naloxone on the guinea-pig ileum. Life Sciences, 18, 803-810.

Van Nueten, J. M., Van Ree, J. M., and Vanhoute, P. M. (1977). Inhibition by met-enkephalin of peristaltic activity in the guinea-pig ileum and its reversal by naloxone. Furopean Journal of Pharmacology, 41, 341-342. 